
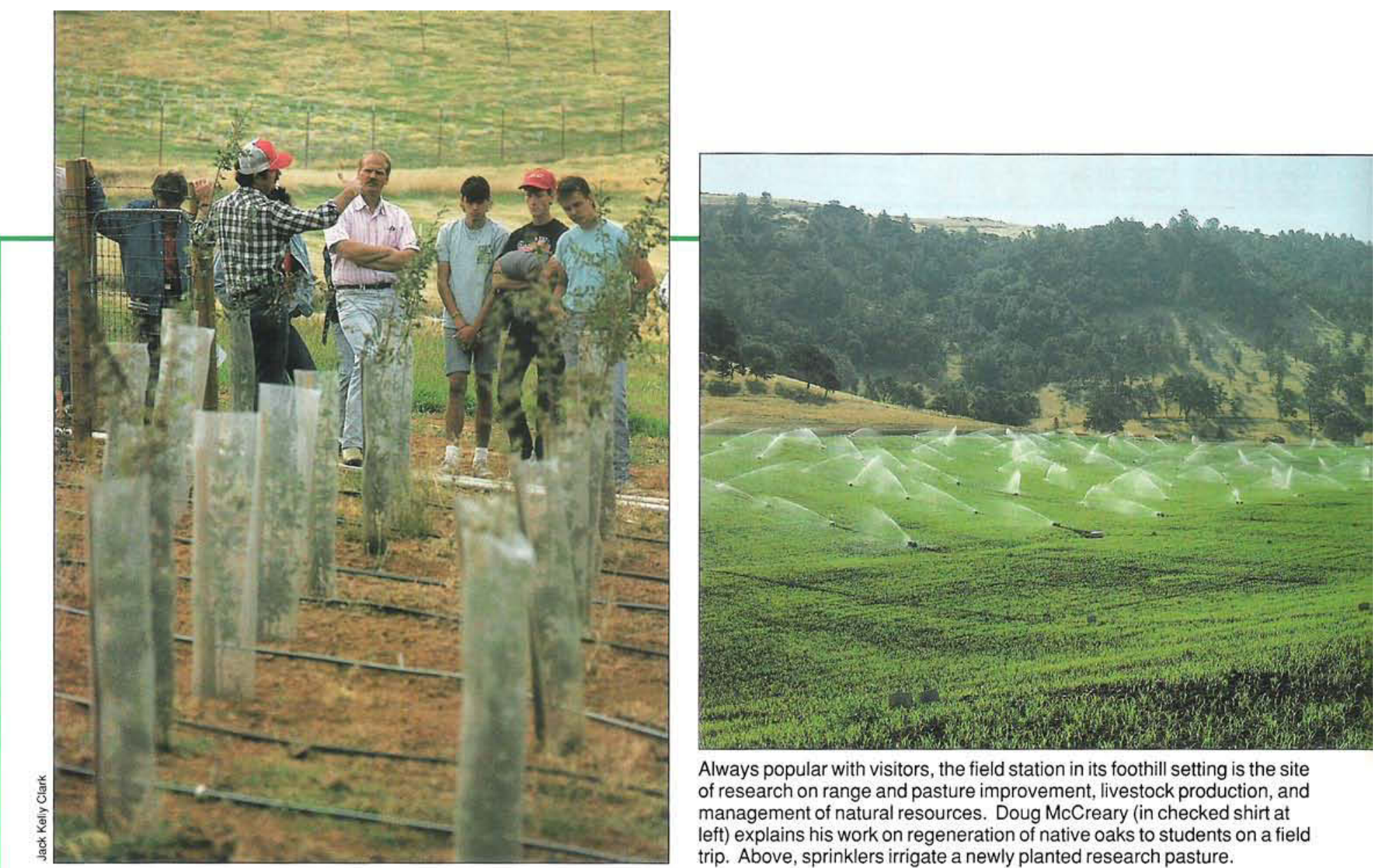

Always popular with visitors, the field station in its foothill setting is the site of research on range and pasture improvement, livestock production, and management of natural resources. Doug McCreary (in checked shirt at left) explains his work on regeneration of native oaks to students on a field trip. Above, sprinklers irrigate a newly planted research pasture.

\title{
Sierra Foothill Range Field Station
}

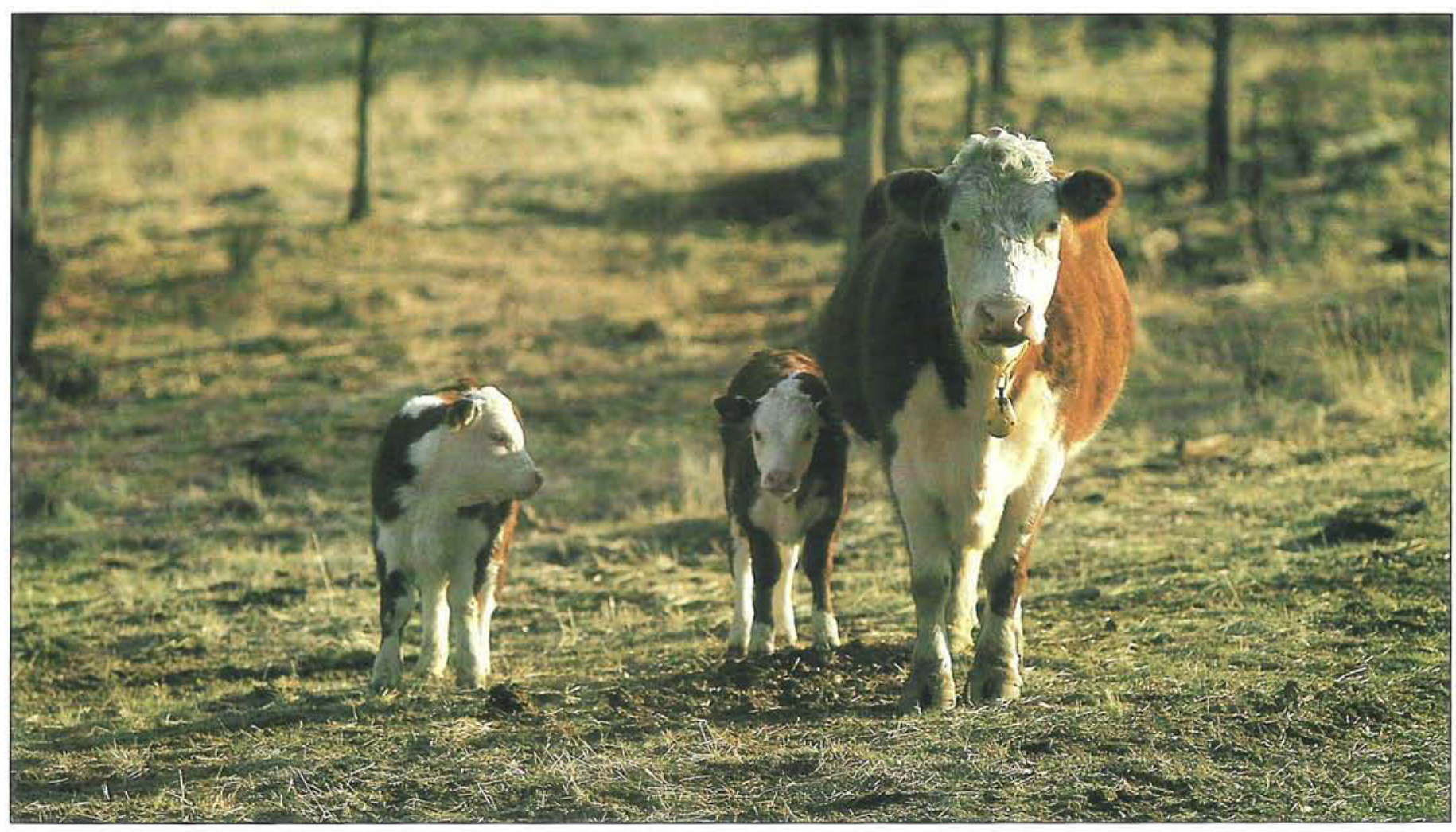

Much of the research on beef cattle at the Sierra Foothill center focuses on management of cow-calf operations. This cow and her twin calves were part of a study of the use of the embryo transfer technique to increase twinning as a possible means of improving production efficiency. 


\title{
Thirty years of research: an overview
}

\author{
Charles A. Raguse $\square$ Gary A. Beall $\square$ John L. Hull $\square$ Douglas McCreary $\square$ Charles B. Wilson
}

The Sierra Foothill Range Field Station, the youngest in a statewide network of nine University of California field stations and research centers, is approaching its 30 th birthday. Operated by the UC Division of Agriculture and Natural Resources, the station was established June 1, 1960, when the University acquired two large parcels of land near Browns Valley in Yuba County.

The station soon became an important field laboratory for research to support livestock and agronomic productivity of foothill rangelands. Over the years, new research dimensions-management of open spaces, watersheds, hardwoods, and wildlife-have been added to accommodate increasing public concern about management of renewable natural resources.

The station's 5,700 acres range in elevation from less than 300 feet along the scenic Yuba River to nearly 2,000 feet in steep, woodlandbrush foothills. The climate, soils, rough terrain, and variety of vegetation types are representative of several million acres of California foothill rangelands.

This report gives an overview of the research program at the station over the last 30 years and complements the following eight companion articles, which discuss current research projects. Additional information about the research and other programs is available from John M. (Mike) Connor, Station Superintendent, Sierra Foothill Range Field Station, P.O. Box 28, Browns Valley, California 95918. Telephone: (916) 639-2501.

\section{Range and pasture development}

Range improvement at the station began with chemical treatment of blue oaks, and several major land parcels were control-burned within a few years. Reseeding, with and without phosphorus and sulfur fertilization, and chemical control of stump sprouts followed the burning. Later, vegetation-type conversions combined harvesting trees for wood, brush piling, and stump resprout control. Water delivery systems for irrigated pastures were improved.

The first agronomic research focused on the adaptation of subterranean and rose clover varieties and an inventory of resident herbaceous vegetation.

Difficulties encountered in attempting to introduce new plants into such a highly disturbed and dynamic ecosystem resulted in at least a decade of research devoted to stand establishment. Chemicals were used to suppress stump sprouting, suppress competition of resident species against those of newly introduced species, and suppress or eliminate aggressive populations of weedy species that thrived in these highly disturbed and open areas.

Chemical sprays were combined with seeding equipment designed for operation on rough land. A highly successful technique involved applying a 12-inch band of contact herbicide on germinated and growing resident vegetation while a series of rolling discs and coulters placed seed and fertilizer in mineral soil beneath new growth and plant litter from the previous year. This technique was refined when research showed that spraying a band of activated carbon directly over the planted seed reduced the effect of the herbicide on seedling growth.

Several range and pasture improvement studies looked at the influence of ecological factors on rangeland productivity. In 1963 a series of fenced plots containing new plant introductions and several fertilizer treatments were installed to sample the effect of slope, soil type, and elevation on plant growth. A more sophisti- cated study using small sensors to determine the influence of slope direction on sunlight received, temperature, and soil moisture found that light is the most important determinant of plant growth differences between north- and south-facing slopes. Two other studies measured condensation of transpirational water by shrub species and seasonal variations in the rate of soil weathering.

On cleared foothill rangelands, dried cow manure can be very slow to decompose, preventing grass from growing over the area it covers. Attempts to introduce Australian dung-burying beetles to break down the dried manure and, at the same time improve soil fertility by burying the manure, were not effective. The beetles were not able to adapt and become established in large enough numbers to have an impact.

Erratic results in a study of rate and time of application of phosphorus and sulfur on clover yield led to additional soil sampling that identified nematode infestation as a contributing factor.

Other rangeland fertilization studies have shown that phosphorus and sulfur are needed if introduced legumes are to do well. These findings were verified by a 3 -year, whole-field grazing experiment concluded in 1985.

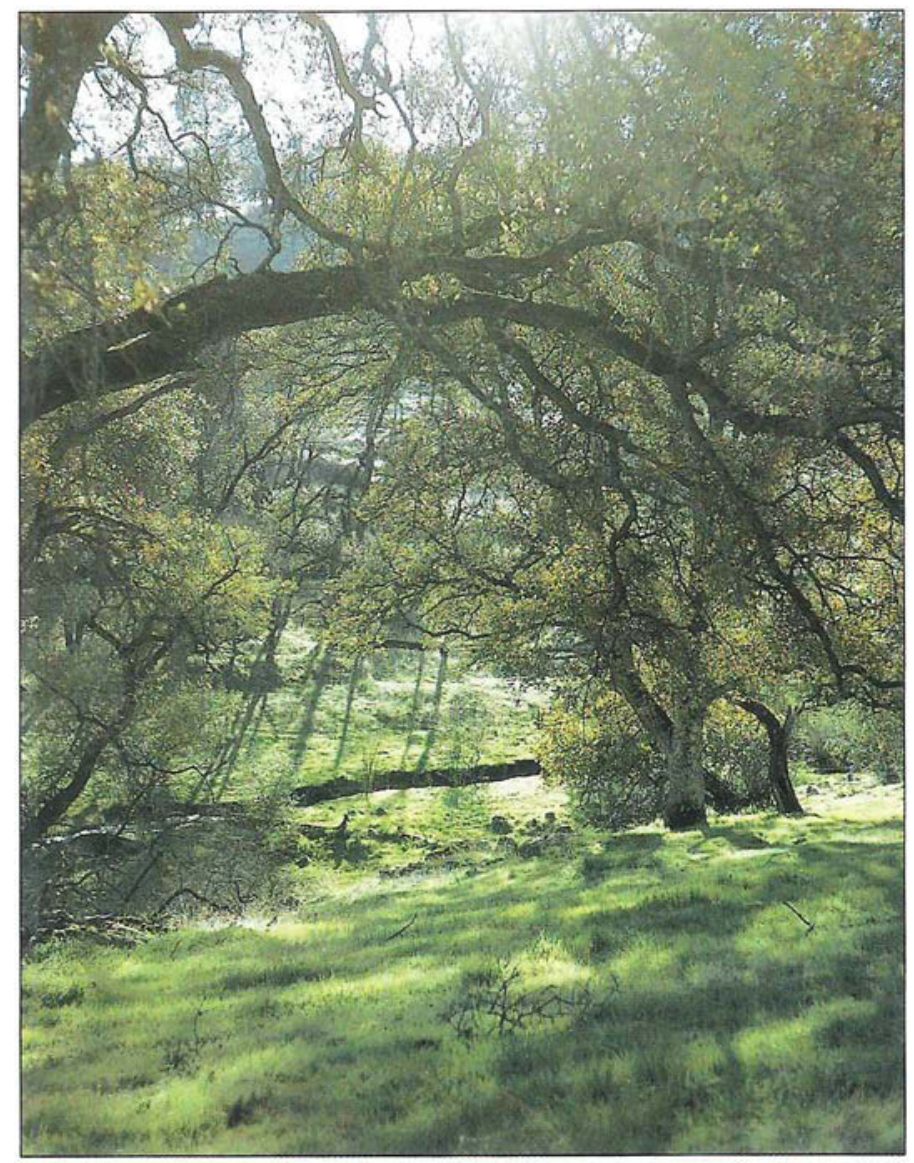

With terrain and climate representative of the northern California foothills, the station provides excellent conditions for studies of native oak woodlands, watersheds, and wildlife. 


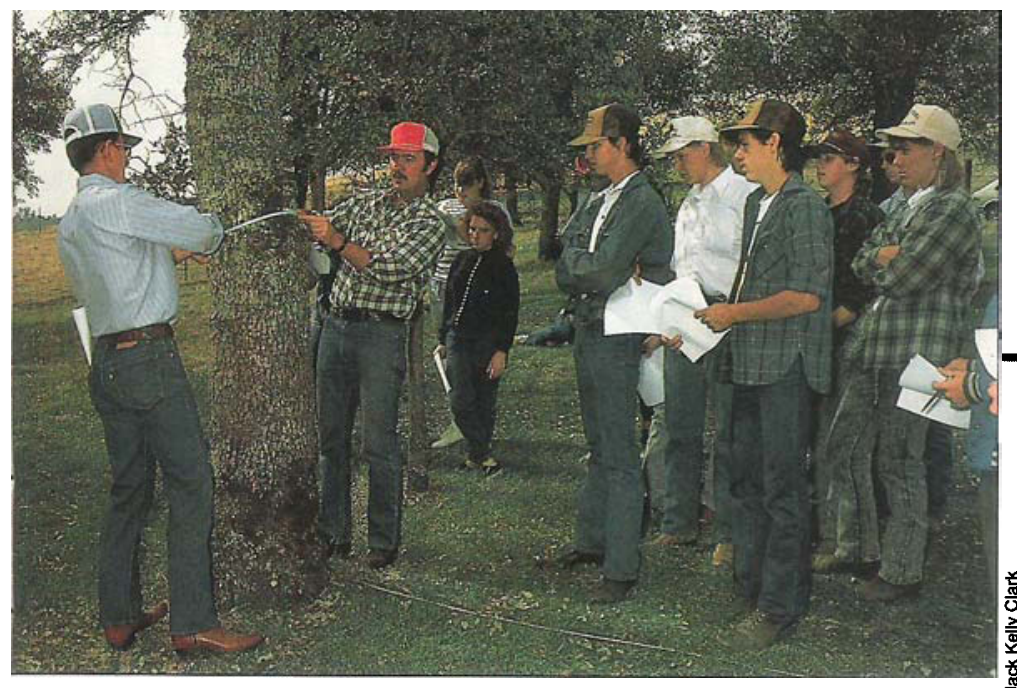

Station Superintendent Mike Connor and Extension Natural Resources Specialist Doug McCreary measure tree diameter in a demonstration of stand evaluation techniques to a group of students.

year-old heifers are exposed to the tick. Changing from spring to fall calving in northern areas and calving in September rather than November in warmer areas of California also are effective management practices to prevent exposure to the tick during the critical stages of pregnancy.

Early studies showed that supplementing range cows with nutrients in which the forage is deficient and that are limiting for animal production can increase calf gains and may enhance rebreeding Recent supplementation studies with protein and energy, however, produced significant responses only for rebreeding of first-calf heifers. Because of the economics involved, supplemental feeding of calves (creep-feeding) on nonsupplemented cows is the only practice that can be recommended from these experiments.

Research on internal parasites has examined seasonal patterns of buildup in beef cattle grazing foothill pastures and the response of the immune system to internal parasite loads. Guidelines were developed for more precise scheduling of available treatment preparations, and coordination of treatment with seasonal changes in pasture use.

Studies also have been done on ear tags for face fly control, selenium supplementation, pinkeye control, energy expenditure by beef steers grazing annual grassland, the development of a method to measure individual cow consumption of supplements, and electronic recording of range cow grazing and rumination behavior.

Trials continue in the areas of cow-calf management, herd health, nutrition, and grazing management.

\section{Natural resource management}

During the last decade, station research has diversified, and wildlife, forestry, soils, and watershed management form an important component of current activities.

An extensive wildlife monitoring project during the last 3 years has provided information about species abundance and use and how population levels change from season to season. Such information is vital to understanding current wildlife resources, and it can also be used to help predict how certain vegetation management practices or events (tree or brush removal, fire, or seeding of legumes) will affect wild life populations in the future. Other wildlife projects have had a more specific focus. For instance, several have examined California quail, including one evaluating social behavior, organization, and reproductive success. Another is examining the effects of brush pile size and loft on use by quail.

The problem of poor oak regeneration is being studied extensively. Some projects are examining factors responsible for poor natural regeneration. Others are evaluating techniques for successfully growing and planting acorns and seedlings. Information from these studies has clarified some of the principal obstacles to successful seedling establishment. It has also provided practical guidelines for artificially regenerating native oaks.
Non-native hardwoods, including eucalyptus and hybrid poplar, are being studied to determine their growth rates and sensitivity to cold. Results will help determine the feasibility of biomass production in the foothills.

Since a third of California consists of rangelands, range management practices can potentially have a large impact on water yield and quality. Research in this area has focused on the effects of rangeland vegetation management on nutrients released to streams, erosion, and changes in water yield. A current study is examining nutrient dynamics among plants, water, and soils in intensively managed hardwood rangelands.

\section{Teaching and public service}

Thestation's teaching activities divide into three categories: class visits and tours; student internships; and student research.

Student interns from northern California colleges and universities, usually partially supported by local or state beef cattle associations, spend a school semester or quarter in residence at the station. They gain practical experience by assisting in cattle management as well as performing field work and data management tasks for various range and livestock research projects.

Results of station research are extended to growers, producers, and the general public through field days, meetings, tours, and onsite visits. The station has provided resources for training farm advisors and professionals from other universities and agencies. It also is popular with foreign visitors.

\section{Conclusions and a forward look}

For the last 30 years, the Sierra Foothill Range Field Station has been an invaluable outdoor laboratory, classroom, and demonstration facility. Research findings have traveled around the world, frequently through the wide distribution of California Agriculture. The station will continue to serve society as research, teaching, and outreach evolve in response to changes in the broad geographical area it represents.

Major contributions can be made to environmental quality through studies of multiple-use management of hardwood rangelands and oak woodlands, water use and quality relationships, and restoration ecology. Current concepts of stability and sustainability in Central Valley cropping systems also have applications in rangeland and pasture production and management.

Long-term research programs with multiple disciplines and objectives, patterned after the National Science Foundation concept of long-term ecological research (LTER), can dramatically expand the value and application of individual studies. Available communications technology and the network of Cooperative Extension advisors, together with representatives of other state and federal agencies, can make the rapid transfer of information to and from the public a reality.

The station, as part of the UC agricultural field station system, thus is well positioned to meet the challenges of the years ahead.

Charles A. Raguse is Professor, Department of Agronomy and Range Science; Gary A. Beall is Communications Specialist, Division of Agriculture and Natural Resources; and John L. Hull is Specialist, Department of Animal Science, all with the University of California, Davis. Douglas McCreary is Extension Natural Resources Specialist, Department of Forestry and Resource Management, UC Berkeley, stationed at the Sierra Foothill Range Field Station; Charles B. Wilson is Farm Advisor and County Director, Cooperative Extension, Sutter and Yuba counties. 